\title{
Esensi Metode Pendidikan: Perspektif Filsafat Pendidikan Islam
}

\author{
Bahrul Ulum \\ Program Studi Pendidikan Bahasa Arab STAI As-Sunnah \\ Jl. Medan-Tg. Morawa, KM 13, Gg. Darmo, Desa Bangun Sari, Kab. D. Serdang \\ Sumut \\ bahrul.ulum1507@gmail.com
}

\begin{abstract}
Abstrak
Metode pendidikan merupakan jembatan yang bisa menghubungkan pendidik dengan peserta didik, seandainya metode ini tidak ada pendidik akan kesulitan dalam menerapkan kurikulum dan tujuan yang ingin dicapainya. Dari uraian singkat diatas dapat kami simpulkan beberapa hal, yaitu ternyata dalam dunia pendidikan memiliki banyak metode pendidikan. Karena dalam pendidikan seorang pendidikan tidak hanya mengenal satu karakter orang saja tetapi banyak karakter, hal ini menyebabkan ketika pendidik sedang mengajar akan menghadapi masalah yang berbeda-beda. Semoga bermanfaat bagi kita semua, khususnya generasi muda yang akan terjun dimasyarakat tentunya harus mempunyai bekal yang matang dan baik. Metode pendidikan sangat penting dalam dunia pendidikan, untuk itu setiap pendidik hendaknya mengetahui tentang metode pendidikan. Bukan saja secara formal tetapi yang tidak formal pun harus diketahui. Banyak para ahli pendidikan dahulu maupun sekarang memformulasikan metode pendidikan, tetapi pada kenyataannya memiliki satu tujuan yaitu membentuk manusia yang terdidik. Pendidikan Islam dalam pelaksanaannya membutuhkan metode yang tepat untuk menghantarkan kegiatan pendidikannya kearah tujuan yang dicita-citakan.
\end{abstract}

Kata Kunci: Kesehatan mental; Covid-19; Tazkiyatun Nafs

\section{Pendahuluan}

Dunia pendidikan saat ini masih dihadapkan pada berbagai persoalan, mulai dari soal rumusan tujuan pendidikan yang kurang sejalan dengan tuntutan masyarakat, sampai kepada persoalan guru, metode, kurikulum dan lain sebagainya.

Filsafat pendidikan Islam secara umum akan mengkaji berbagai masalah yang terdapat dalam dunia pendidikan. Misalnya berkaitan dengan masalah metode pendidikan seperti yang akan kita bahas dalam makalah ini. Untuk itu perlu untuk kita ketahui apa yang dimaksud dengan metode pendidikan Islam, serta metodemetode apa saja yang terdapat dalam dunia pendidikan.

Pendidikan Islam dalam pelaksanaannya membutuhkan metode yang tepat untuk menghantarkan kegiatan pendidikannya kearah tujuan yang dicita-citakan. Bagaimanapun baik dan sempurnanya suatu kurikulum pendidikan Islam, ia tidak akan berarti apa-apa manakala tidak memiliki metode atau cara yang tepat dalam mentransformasikannya kepada peserta didik. Ketidaktepatan dalam penerapan metode secara praktis akan menghambat proses belajar mengajar, karenanya metode adalah syarat untuk efisiennya aktivitas kependidikan Islam. 


\section{Hasil dan Pembahasan}

\section{Pengertian Metode Pendidikan Islam}

Metode berasal dari bahas latin meta yang berarti " melalui", dan hodos yang berarti " jalan ke" atau "cara ke". Dalam bahasa arab, metode disebut tariqah artinya “ jalan","cara","system” atau " ketertiban" dalam mengerjakan sesuatu. Sebagai istilah, metode berarti suatu system atau cara yang mengatur suatu cita-cita. ${ }^{1}$ Dalam pandangan filosofis pendidikan, metode merupakan alat yang dipergunakan untuk mencapai tujuan pendidikan.

a. Pengertian Pendidikan Islam

Banyak para pakar pendidikan yang mendefinisikan pendidikan secara berbeda-beda tetapi pada intinya sama.

1. Pendidikan dari segi bahasa berasal dari kata dasar didik, dan diberi awalan men-, menjadi mendidik, yaitu kata kerja yang artinya memelihara dan memberi latihan ( ajaran). Pendidikan sebagai kata benda berarti proses perubahan sikap dan tingkah laku seseorag atau kelompok orang dalam mendewasakan manusia melalui upaya pengajaran dan latihan. Pendidikan, yaitu pendewasaan diri melalui pengajaran dan latihan.

2. Pendidikan suatu aktivitas masyarakat yang berfungsi mentranformasikan keadaan yang lebih baik. Keterkaitan pendidikan dengan masyarakat sangat erat.pendidikan mengalami proses spealisasi dan institusional sesuatu dengan kebutuhan masyarakat yang kompleks dan modern. Proses pendidikan tersebut secara universal tidak bisa dilepaskan dari proses pendidikan informal yang berlangsung di luar sekolah. Dengan demikian, keterkaitan keluarga dan lingkngan masyarakat sangat signifikan.

3. Istilah pendidikan berasal dari bahasa inggris education, to educate, yaitu mengasuh, mendidik. Dalam dictionary of education, makna education adalah kumpulan semua proses yang memungkinkan seseorang mengembangkan kemampuan, sikap-sikap, dan bentuk-bentuk tingkah laku yang positif di dalam masyarakat tempat ia hidup.istilah education juga bermakna sebuah proses social tatkala seseorang dihadapkan pada pengaruh lingkungan yang terpilih dan terkontrol (khususnya lingkungan social) sehingga mereka dapat memiliki kemampuan social dan perkembangan individual secara optimal.

4. Pendidikan adalah usaha yang dilakukan sengaja dam sistematis untuk memotivasi, membina, membantu, serta membimbing seseorang untuk mengembangkan segala potensinya sehingga ia mencapai kualitas diri

${ }^{1}$ Muhammad Sudiyono, Ilmu Pendidikan Islam (Jakarta: Rineka Cipta, 2009), hal.180. Jurnal WARAQAT • Volume V, No. 2, Juli - Desember 2020 | 
yang lebih baik. Inti dari pendidikan adalah usaha pendewasaan seutuhnya ( lahir dan batin), baik oleh orang lain maaupun oleh dirinya sendiri, dalam artian tuntutan yang menuntun agar anak didik memiliki kemerdekaan berpikir, merasa, berbicara, dan bertindak, serta percaya diri dengan penuh rasa tanggung jawab dalam setiap tindakan dan perilaku kehidupanya sehari -hari.

5. Pendidikan merupakan usaha pengembangan kualitas diri manusia dalam segala aspeknya. Pendidikan sebagai aktivitas yang disengaja untuk mencapai tujuan tertentu da melibatkan berbagi faktor yang paling berkaitan antar satu dengan yang lainnya, sehingga membentuk satu system yang saling mempengaruhi. ${ }^{2}$

Marimba (1989:19) menyatakan bahwa pendidikan adalah bimbingan atau pimpinan secara sadar oleh pendidik terhadap perkembangan jasmani dan ruhani anak didik menuju terbentuknya kepribadian yang utama 3

Setelah membahas Pendidikan selanjutnya kita akan memaparkan tentang pendidikan Islam. Berikut ini adalah beberapa pengertian Pendidikan Islam secara terminologi yang diformulasikan oleh para ahli Pendidikan Islam, diantaranya adalah:

a) Menurut Al-Syaibaniy mengemukakan bahwa pendidikan Islam adalah usaha mengubah tingkah laku individu dalamkehidupa pribadinya atau kehidupan kemasyarakatannya dan kehidupan alam sekitarnya melalui proses kependidikan. ${ }^{4}$

b) Menurut Muhammad Fadhil al-Jamaly, mendefinisikan pendidikan Islam sebagai proses yang mengarahkan manusia kepada kehidupan yang baik da yang mengangkat derajat kemanusiaanya sesuai dengan kemampuan dasar (fitrah) dan kemampuan ajarnya (pengaruh luar). ${ }^{5}$

c) Hasil rumusan seminar pendidikan Islam se- Indonesia tahun 1960, memberikan pengertian pendidikan Islam: " sebagai bimbingan terhadap pertumbuhan rohani dan jasmani menurut ajaran Islam dengan hikmah mengarahkan, mengajarkan, melatih, mengasuh, dan mengawasi berlakunya semua ajaran Islam. ${ }^{6}$

d) Menurut Arrasyidin, pendidikan Islami dapat didefinisikan sebagai suatu proses penciptaan lingkungan yang kondusif bagi memungkinkan manusia sebagai peserta didik untuk mengembangkan diri-fisik-jasmani

${ }^{2}$ Muhammad Daryanto, Adminisrtasi Dan Manajemen Sekolah ( Jakarta : Rineka Cipta, 2013), hal 81 .

${ }^{3}$ Ahmad Tafsir, Ilmu Pendidikan Islam, (Bandung: PT Remaja Rosdakarya, 2013) hal 34.

${ }^{4}$ Perkataan Omar Muhammad Al-Touny al-Syaebani, Muzayyin Arifin, Filsafat

Pendidikan Islam ( Jakarta: Bumi Aksara, 2014), h. 15

${ }^{5}$ Ibid, h. 18

${ }^{6}$ Ibid, h 15 
dan non fisik-ruhani- dan potensi yang dimilikinya- aljism, a'aql, al-nafs, dan al- qalb- agar berkemampuan merealisasikan syahadah primordialnya terhadap keberadaan dan kemahaesaan Alloh Ta'ala, melalui pemenuhan fungsi dan tugas penciptaannya, yakni sebagai 'abd Allah dan Khalifah Allah. ${ }^{7}$

\section{Dasar dan Karakteristik Metode Pendidikan Islam}

Dari beberapa pengertian yang diformulasikan oleh para pakar diatas tentang pengertian Metode dan Pendidikan Islam. Kita dapat menyimpulkan tentang pengertian Metode Pendidikan. Seperti yang dikemukakan oleh al-Syaibaniy yaitu, segala segi kegiatan yang terarah yang dikerjakan oleh guru dalam rangka kemestian-kemestian mata pelajaran yang diajarkannya, ciri-ciri perkembangan peserta didiknya, dan suasana alam sekitarnya dan tujuan membimbing peserta didik untuk mencapai proses belajar yang diinginkan dan perubahan yang dikehendaki pada tingkah laku mereka.

Selanjutnya jika kata metode tersebut dikaitkan dengan pendidikan Islam, dapat membawa arti sebagai jalan untuk menanamkan pengetahuan agama pada diri seseorang sehingga dapat terlihat dalam pribadi objek sasaran, yaitu pribadi Islami. Selain itu metode pendidikan Islam dapat diartikan sebagai cara untuk memahami, menggali, dan mengembangkan ajaran Islam, sehingga terus berkembang sesuai dengan perkembangan zaman.

a. Dasar agama, yaitu merujuk atau menjadikan Al-Quran sebagai landasan atau dasar pertimbangan dalam memilih dan menetapkan metode yang digunakan dalam pembelajaran. Setelah itu baru kemudian menggunakan sumber-sumber lain dengan berbagai cabangnya dan dari penggalan serta praktik orang-orang shalih terdahulu.

b. Dasar biologis, yaitu landasan atau pertimbangan yang didasarkan pada keadaan dan kebutuhan jasmani peserta didik serta tingkat perkembangan dan usia mereka.

c. Dasar psikologis, yaitu pertimbangan terhadap sejumlah kekuatan psikologis, seperti motivasi, kebutuhan, emosi, minat, sikap, keinginan, kesediaan, bakat-bakat, dan kecakapan intelektual peserta didik.

d. Dasar social, yaitu mempertimbangkan latar social lingkungan peserta didik, termasuk nilai-nilai dan tradisi-tradisi yang berlakudi masyarakat didalam memilih dan menetapkan metode pembelajaran. ${ }^{8}$

${ }^{7}$ Al Rasyidin, Falsafah Pendidikan Islam; membangun kerangka ontology, epistemology, dan aksiologi praktik pendidikan Islam,( Bandung; Citpustaka Media Perintis, 2015) hal. 119

${ }^{8}$ Al Rasyidin, hal. 179-180 
Metode pendidikan Islam harus digali, didayagunakan, dan dikembangkan dengan mengacu pada asas-asas sebagaimana yang dikemukakan diatas. Melalui aplikasi nilai-nilai Islam dalam proses penyampaian seluruh materi pendidikan Islam, diharapkan proses itu dapat diterima, difahami, dihayati, dan diyakini sehingga pada gilirannya memotivasi peserta didik untuk mengamalkannya dalam bentuk nyata.

Adapun karakteristik Metode pendidikan Islam sebagaimana yang disebutkan Arrasyidin9, diantaranya:

1. Penerapan dan pengembangannya didasarkan pada nilai-nilai Islam

2. Berorientasi pada penegakan al-akhlaq al-karimah

3. Keseimbangan antara teori dan praktek

4. Menekannkan nilai-nilai keteladanan (Mencontoh Rasul)

5. Menekankan kebebasan berkreasi dan mengambil prakarsa

6. Mendepankan dialog kreatif (hikmah, pengajaran, dan argumentasi)

7. Mempermudah proses pembelajaran.

\section{Jenis Metode Dalam Pendidikan Islam}

Sebagai ummat yang telah dianugerahi Allah Kitab AlQuran yang lengkap dengan petunjuk yang meliputi seluruh aspek kehidupan dan bersifat universal sebaiknya menggunakan metode mengajar dalam pendidikan Islam yang prinsip dasarnya dari Al Qur'an dan Hadits. Diantara metode- metode tersebut dapat diterapkan dengan maksud dan tujuan tertentu diantanya:

1. Menalar al-'ilm, maka metode yang digunakan diantaranya; metode membaca (Iqra) ${ }^{10}$, metode ceramah, ${ }^{11}$ metode dialog ${ }^{12}$, metode diskusi ${ }^{13}$, metode musyawarah ${ }^{14}$, metode perdebatan $^{15}$, metode mengajukan pertanyaan, ${ }^{16}$ metode perumpamaan ${ }^{17}$, metode perbandingan, metode perenungan, ${ }^{18}$ metode analogi, dan sebagainya;

\footnotetext{
${ }^{9}$ Ibid. hal 180

${ }^{10}$ Q.S al- 'Alaq :1-5

${ }^{11} Q ; S$ Yunus:23

12 Q:S al An'am :76-79

${ }_{13}^{13}$ Q.S. Assafat : 20-23

${ }^{14}$ Q:S Ali Imran : 159

${ }^{15}$ Q:S An-Nahl: 125

${ }^{16} \mathrm{Q}:$ S al-Rahman : 1-78

${ }^{17}$ Q:S al-Baqorqh : 26

${ }^{18}$ Q;S al-Thariq: 5-10
} 
2. Memahami al-ilm, maka metode yang digunakan diantaranya; metode perenungan( tafakur), metode qishah, ${ }^{19}$ metode pengulangan, dan sebagainya;

3. Mensucikan jiwa, maka metode yang digunakan diantaranya; metode pemeliharaan jiwa, metode pensucian jiwa ( tazkiyatul Al-nafs), ${ }^{20}$ metode pemberian nasihat (mauizhoh), ${ }^{21}$ metode intropeksi atau evaluasi diri (muhasabah al-nafs), metode pemberian peringatan, metode qishah, dan sebagainnya.

4. Mendisiplinkan jasmaninya, diantara metode yang dipakai; metode latihan, metode pembiasaan, metode demontrasi, ${ }^{22}$ metode pemberian nasihat, metode rihlah, ${ }^{23}$ dan sebagainya.

\section{Dasar Pertimbangan Dalam Penetapan Metode}

Ada tiga aspek yang sangat penting, berkenaan dengan tugas yang sepenuhnya sadar akan kewajibannya sebagai seorang pendidik muslim, pertama, hakekat metoda dan relevansinya dengantuhuan utama pendidikan Islam, yakni membentuk pribadi orang beriman yang senantiasa siap sedia mengabdi kepada Allah Ta'ala. Kedua, mengadakan penelitian tentang aktualisasi metoda-metoda intruksional yang ditunjukan Alqu'an atau yang dapat dideduksian padanya. Ketiga, berkenaan dengan pemberian motivasi atau disiplin, atau term-term Al-Quran tentang ganjaran atau hukuman tsawab atau iqab. ${ }^{24}$

Untuk memudahkan proses men-ta'limkan, men-tarbiyah, atau menta'dibkan al-ilm kedalam diri peserta didik, maka metode pendidikan Islami yang digunakan pendidik juga harus bervariasi, mengingat konsepsi kedirian manusia terdiri dari jasmani dan ruhani. Sesuatu yang perlu diketahui juga, bahwa bahwa tidak ada metode yang bisa digunakan untuk semua bahan dan tujuan pembelajaran, oleh karena itu hal-hal penerapan metode yang perlu di pertimbangkan, sebagaimana yang dikatakan Arrasyidin, ${ }^{25}$ sebagai berikut:

a. Tujuan dan target yang ingin dicapai;

b. Ruang lingkup dan urutan materi/bahan pembelajaran;

c. Pertumbuhan dan perkembangan fisik dan psikologis peserta didik;

${ }^{19}$ Q:S Hud:120

${ }^{20}$ Q:S al-Taubah: 108

${ }^{21} \mathrm{Q}: \mathrm{S}$ al-Nahl: 125

${ }^{22}$ Q:S Al-Maidah : 31

${ }^{23}$ Q:S al-Kahfi 60-82

${ }^{24}$ Abdurahman Saleh Abdullah, Teori-teori Pendidikan Berasarkan Al-qur'an ( Jakarta:Rineka Cipta, 2007), hal 198.

${ }^{25}$ Al Rasyidin, Falsafah Pendidikan Islam; membangun kerangka ontology, epistemology, dan aksiologi praktik pendidikan Islam,( Bandung; Citpustaka Media Perintis, 2015) hal. 179 
d. Kebutuhan dan karakteristik peserta didik;

e. Motivasi/minat peserta didik

f. Kemampuan peserta didik dalam melakukan sesuatu;

g. Ukuran kelas dan suasana lingkungan pembelajaran;

h. Alokasi waktu atau jam pembelajaran yang tersedia;

i. Kemampuan pendidik, dan

j. Sarana dan fasilitas pembelajaran yang tersedia.

Dengan demikian penerapan metode pendidikan Islami sesuai

pertimbangan asas asas yang telah disebutkan dapat dilaksanakan dengan baik.

\section{Penutup}

Dari uraian singkat diatas dapat kami simpulkan beberapa hal, yaitu ternyata dalam dunia pendidikan memiliki banyak metode pendidikan. Karena dalam pendidikan seorang pendidikan tidak hanya mengenal satu karakter orang saja tetapi banyak karakter, hal ini menyebabkan ketika pendidik sedang mengajar akan menghadapi masalah yang berbeda-beda. Disamping itu metode pendidikan merupakan jembatan yang bisa menghubungkan pendidik dengan peserta didik, seandainya metode ini tidak ada pendidik akan kesulitan dalam menerapkan kurikulum dan tujuan yang ingin dicapainya.

Semoga bermanfaat bagi kita semua, khususnya generasi muda yang akan terjun dimasyarakat tentunya harus mempunyai bekal yang matang dan baik. tersebut.

hal yang akan dilakukan terkait dengan gagasan selanjutnya dari penelitian

\section{Daftar Pustaka}

Abdurahman Saleh Abdullah, Teori-teori Pendidikan Berdasarkan Alqur'an. Jakarta: Rineka cipta, 2007.

Ahmad Tafsir, Ilmu Pendidikan Islam. Bandung: PT Remaja Rosdakarya, 2013

Ar-Rasyidin, Falsafah Pendidikan Islami; Membangun kerangka ontology, epistomologi dan aksiologi praktik pendidikan. Cita Pustaka Media Perintis, 2015.

Muhammad Daryanto, adminisrtasi dan Manajemen Sekolah. Jakarta : Rineka Cipta, 2013

Muhammad Sudiyono, Ilmu Pendidikan Islam.Jakarta: Rineka Cipta, 2009

Muzayyin Arifin , Filsafat Pendidikan Islam, Jakarta: Bumi Aksara, 2014. 
